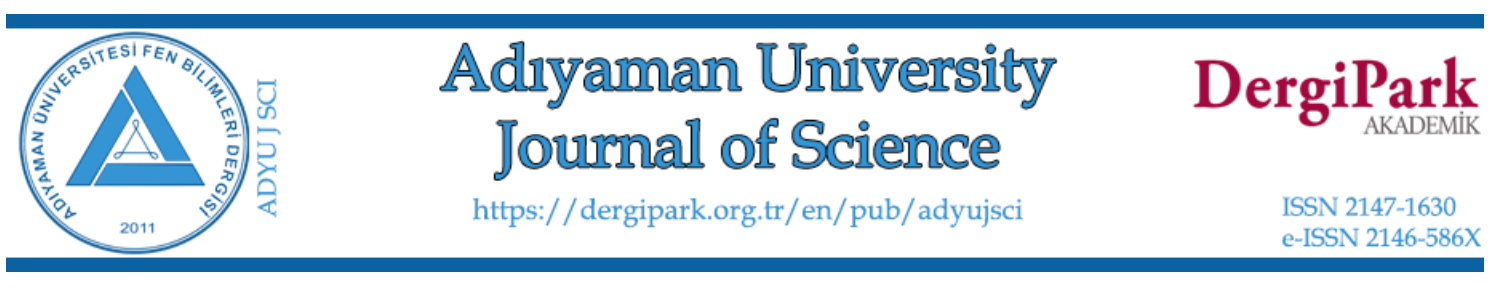

\title{
Synthesis and Optical, Thermal, Structural Investigation of Zinc-Borate Glasses
}

\section{Containing $\mathrm{V}_{2} \mathrm{O}_{5}$}

\author{
Gökhan KILIÇ⿻,* \\ ${ }^{I}$ Eskisehir Osmangazi University, Faculty of Science and Letters, Department of Physics, TR-26040 \\ Eskisehir, Turkey \\ gkilic@ogu.edu.tr,ORCID: 0000-0002-6762-6898
}

\begin{tabular}{lll}
\hline Received: 22.01.2020 & Accepted: 27.02.2020 & Published: 25.06.2020
\end{tabular}

\begin{abstract}
Vanadium pentaoxide $\left(\mathrm{V}_{2} \mathrm{O}_{5}\right)$ doped zinc borate $(\mathrm{ZnB})$ oxide glasses that could be used in fiber optic cable cores in optoelectronics, in laser crystals in solar energy systems have been synthesized successfully. Structural characters of synthesized glasses were determined with differential scanning calorimeter (DSC) and Fourier-Transform infrared spectroscopy (FTIR). Glass transition $\left(T_{g}\right)$, crystallization $\left(T_{c}\right)$ and melting temperatures $\left(T_{m}\right)$, and thermal stabilities $(\Delta T)$ of the glasses were determined and also their association with the change in $\mathrm{V}_{2} \mathrm{O}_{5}$ was explained. Structural units of boron and zinc that form the structure were determined according to FTIR data. As a result, it was determined that boron formed the glass matrix with $\mathrm{BO}_{3}, \mathrm{BO}_{4}$ and boroxol ring structural units; on the other hand, zinc contributed to the glass matrix with tetrahedral $\mathrm{ZnO}_{4}$ and octahedral $\mathrm{ZnO}_{6}$ structural units, and vanadium usually had modifier role in the structure with its $\mathrm{VO}_{4}$ and $\mathrm{VO}_{5}$ structural units. $\mathrm{V}_{2} \mathrm{O}_{5}$ 's presence in the structure with increasing amount changes thermal, structural and physical properties. Among the properties that significantly change, the most important one is optical properties. Indirect optical band gaps, Urbach energies, refractive index values of these synthesized samples were determined, and quite clear shifts towards red region were observed in the transmittance and absorption spectra. Optical band gap decreased to $1.24 \mathrm{eV}$ from $2.55 \mathrm{eV}$ with increasing amount of $\mathrm{V}_{2} \mathrm{O}_{5}$; on the other hand,
\end{abstract}


Urbach energy was determined to increase to $0.630 \mathrm{eV}$ from $0.246 \mathrm{eV}$. Densities, molar volumes of these synthesized glasses were also examined and commented on.

Keywords: $\mathrm{ZnO} ; \mathrm{B}_{2} \mathrm{O}_{3} ; \mathrm{V}_{2} \mathrm{O}_{5}$; Zinc-Borate glass; FTIR.

\section{$\mathrm{V}_{2} \mathrm{O}_{5}$ İçeren Çinko-Borat Camların Sentezi ve Optik, Termal, Yapısal İncelenmeleri}

\section{Öz}

Optoelektronikte fiber optik kablo korlarında, laser kristallerinde ve güneş enerji sistemlerinde kullanılabilecek vanadium pentaoksit $\left(\mathrm{V}_{2} \mathrm{O}_{5}\right)$ katkılı çinko borat $(\mathrm{ZnB})$ oksit camlar başarıyla sentezlenmiştir. Sentezlenen camlara ait yapısal karakterler diferansiyel taramalı kalorimetre (DSC) ve Fourier dönüşümlü kızılötesi spektroskopisi (FTIR) ile belirlenmiştir. Camsı geçiş $\left(T_{g}\right)$, kristallenme $\left(T_{c}\right)$, erime sıcaklıkları $\left(T_{m}\right)$ ve termal kararlı1ıklar $(\Delta T)$ belirlenerek $\mathrm{V}_{2} \mathrm{O}_{5}$ değişimiyle ilgisi açıklanmıştır. FTIR verilerine göre yapıyı oluşturan bor ve çinkonun yapısal birimleri belirlenmiştir. Borun cam matrisini $\mathrm{BO}_{3}, \mathrm{BO}_{4}$ ve boroksol halka yapısal birimleriyle oluşturduğu, çinkonun ise cam matrisine tetrahedral $\mathrm{ZnO}_{4}$ ve oktahedral $\mathrm{ZnO}_{6}$ yapısal birimleri ile katkıda bulunduğu, vanadyumun yapıda çoğunlukla $\mathrm{VO}_{4}$ ve $\mathrm{VO}_{5}$ yapısal birimleriyle yer alarak düzenleyici görev üstlendiği belirlenmiştir. $\mathrm{V}_{2} \mathrm{O}_{5}$ katkısının artması yapının termal, yapısal ve fiziksel özelliklerini değiştirmektedir. Belirgin biçimde değiştirdiği özelliklerin başında optik özellikler gelmektedir. Sentezlenen numunelere ait indirekt optik bant aralığı, Urbach enerjisi, kırılma indisi değerleri belirlenmiş, geçirgenlik ve absorpsiyon spektrumlarında kırmızı dalgaboyuna kaymalar net bir şekilde gözlenmiştir. Optik bant aralığ $1 \mathrm{~V}_{2} \mathrm{O}_{5}$ artışıyla 2.55 $\mathrm{eV}$ dan 1.24 eV'a azalmış, buna karşılık Urbach enerjisi $0.246 \mathrm{eV}$ 'dan $0.630 \mathrm{eV}$ 'a arttı̆ğ belirlenmiştir. Ayrıca, sentezlenen numunelere ait yoğunluk, molar hacim incelenmiş ve yorumlanmıştır.

Anahtar Kelimeler: $\mathrm{ZnO} ; \mathrm{B}_{2} \mathrm{O}_{3} ; \mathrm{V}_{2} \mathrm{O}_{5}$; Çinko-Borat cam; FTIR.

\section{Introduction}

Glass, an amorphous material, has an important place in respect to technology and science. Besides silicon dioxide $\left(\mathrm{SiO}_{2}\right)$, phosphorus pentoxide $\left(\mathrm{P}_{2} \mathrm{O}_{5}\right)$, boron oxide $\left(\mathrm{B}_{2} \mathrm{O}_{3}\right)$, and vanadium pentoxide $\left(\mathrm{V}_{2} \mathrm{O}_{5}\right)$ are being used in the synthesis of glasses the most. Among these, $\mathrm{B}_{2} \mathrm{O}_{3}$ is known to be the best glass former $[1,2]$. Borate glasses in which $\mathrm{B}_{2} \mathrm{O}_{3}$ establishes the glass network are very important optical materials due to their low melting points, high transmittance properties and high thermal stabilities [3]. They are frequently being used in the making of dielectric materials and used as isolation materials. Though they are being used as dielectric materials, the inclusion 
of transition metal ions in the borate glass network leads to the achievement of semiconductor character or these glasses. Transition metals are nowadays being extensively used in glass science due to their presence in two or more valance states that alters the structural and optical characters [4-10].

It is possible to find examination studies performed on binary zinc-borate structures among transition metal doped borate glasses and also ternary structures and structures having more components in the literature [11-22]. Except for glass systems, it is possible to find zinc-borate ceramic structures, as well [23].

Zinc-borate glasses are being used in plasma screens and panels for high quality and performance [24, 25]. Zinc-borate glasses are promising materials for a large field including television panels and computer monitors. They are preferred due to having high voltage resistance in providing rapid surge in dielectric layers and being highly transparent. Since zinc borate glasses that do not contain lead possess all the aforementioned qualities, they are shown to be appropriate materials for applications that are in question [26].

Studies on vanadium due to their interesting optical, electrical and magnetic properties have significantly increased recently. Though studies on transition metal doped glasses can be found in the literature frequently [27-37], there are still components, compositions and properties that have not yet been studied. Glasses containing vanadium, which is a transition metal, show semiconducting properties since they contain $\mathrm{V}^{4+}, \mathrm{V}^{5+}$ valance states [38-45]. Vanadium doped glasses are known to be n-type semiconductors for low $\mathrm{V}^{4+} / \mathrm{V}^{5+}$ ratio [46]. Glasses with vanadium content have a wide range of use from the production of solid-state devices to memory and optical switching, devices like electrical threshold, and in the formation of fiber optics [47, 48]. Therefore, they are materials with potential for most electronic and optoelectronic applications [49]. In the literature, some characteristics of glasses having different compositions as a result of combining zinc-borate glass systems with $\mathrm{V}_{2} \mathrm{O}_{5}$ have been elaborated $[50,51]$.

In this study, $\mathrm{ZnO}-\mathrm{B}_{2} \mathrm{O}_{3}-\mathrm{V}_{2} \mathrm{O}_{5}$ glasses doped with $\mathrm{V}_{2} \mathrm{O}_{5}$ and containing high ratio of $\mathrm{ZnO}$, so they can find a use in optoelectronics were synthesized successfully. Compared borate glasses that are sensitive to humidity, these synthesized glasses are resistant to air, water; therefore, they are considered to be important since boron is able to find use in respect to technological applications. Structural and thermal properties of these synthesized glasses were examined in a detailed way and discussed. Characterization of this structure considered to become a potential material that could be used in fiber cable cores in optoelectronics, in laser settings and, also in solar energy systems was revealed. 


\section{Materials and Methods}

\subsection{Sample preparation}

ZnO- $\mathrm{B}_{2} \mathrm{O}_{3}$ glass samples containing $\mathrm{V}_{2} \mathrm{O}_{5}$ were synthesized from chemicals having $99.5 \%$ purity (Alfa Aesar) according to $(100-x)\left(0.6 \mathrm{ZnO}-0.4 \mathrm{~B}_{2} \mathrm{O}_{3}\right) .(x)\left(\mathrm{V}_{2} \mathrm{O}_{5}\right)(x=1,2,3,4)$ composition. The method that was used in the synthesis of the glasses was melt-quenching method. Chemicals were weighed on an analytical scale having accuracy of $0.00001 \mathrm{~g}$, and then weighed chemicals were mechanically mixed for approximately $10 \mathrm{~min}$ and made uniform.

Prepared powder mixture was left in a porcelain crucible for 60 minutes in a Nabertherm LHT $02 / 17 \mathrm{LB}$ brand high temperature furnace that was previously heated to $1100{ }^{\circ} \mathrm{C}$ for reaction to take place. At the end of the process, molten glass samples were shaped cylindrically in a steel mold and annealed for 60 minutes at $400{ }^{\circ} \mathrm{C}$.

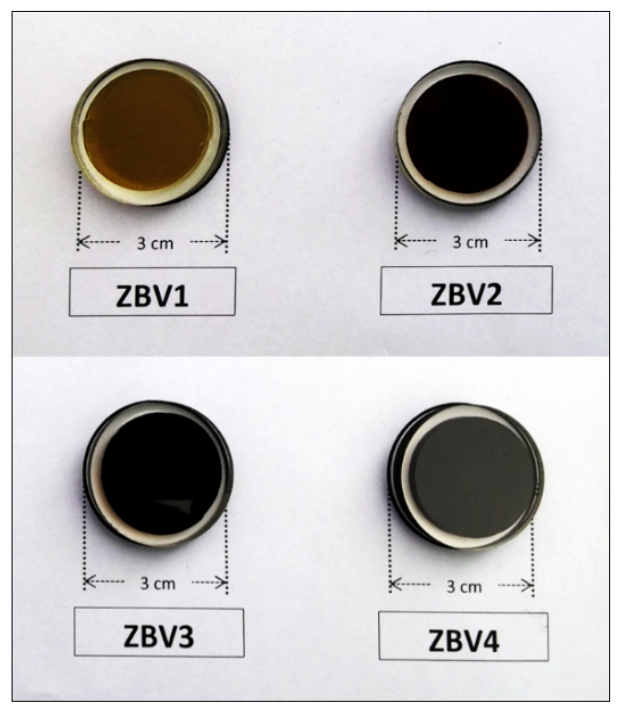

Figure 1: Synthesized $\mathrm{ZnO}-\mathrm{B}_{2} \mathrm{O}_{3}-\mathrm{V}_{2} \mathrm{O}_{5}$ glass samples

Glass samples synthesized by this way (Fig. 1) were sliced with a Metkon brand Micracut 152 model cutting device with diamond disc for optical measurements having a diameter of 2.5 $\mathrm{cm}$ and a thickness of $2 \mathrm{~mm}$; both surfaces of the cut samples were polished with a Metkon brand Forcipol 102 model polishing device. Some of the samples were grounded with a Retsch RM200 brand grinder to study their thermal and structural properties.

\subsection{Characterization}

Densities of glasses were determined with the principle of Archimedes. Samples were first weighed in the air with a KERN brand ABT 100-5m model analytical scale having an accuracy of $0.00001 \mathrm{~g}$, and then weighed again in immersion fluid. Ultra-pure water was selected as 
immersion fluid. By using the measurements taken in the air and in the immersion fluid, densities of the samples were calculated with the below equation [52]:

$$
D=\frac{W_{a}}{W_{a}-W_{l}} \cdot \rho_{o}
$$

In this equation, $W_{a}$ is the weight of the sample in the air, $W_{l}$ is the weight of the sample in the fluid and $\rho_{o}$ is the density of immersion fluid $\left(\rho_{o}=0.998272{\mathrm{~g} . \mathrm{cm}^{-3}}^{-3}\right)$ at $20^{\circ} \mathrm{C}$. Molar volumes $\left(V_{m}\right)$ of glass samples were calculated with the following equation:

$$
V_{m}=\frac{\sum x_{i} M_{i}}{D}
$$

Here, $x_{i}$ is the mole ratio of the $i^{t^{t h}}$ component, $M_{i}$ is the molecular weight.

Transmittance and absorption spectra of the glasses were determined with Analytik Jena SPECORD 210 UV-Vis Spectrophotometer with steps of $1 \mathrm{~nm}$. In addition, in order to determine the uniformity of the sample, transmittance spectra were determined with scanning attachment of the device by using $1.5 \mathrm{~cm}$ piece of the surface. Absorption spectra were used to calculate optical band gaps and Urbach energies of the synthesized samples.

Refractive index due to optical band gap was calculated with the following empirical relation [53]:

$$
\frac{\left(n^{2}-1\right)}{\left(n^{2}+2\right)}=1-\sqrt{\frac{E_{0}}{20}}
$$

$n$, is the refractive index of the samples, $E_{0}$ is optical band gap.

In order to determine the structural properties, powdered forms of the samples were used and their FTIR spectra were obtained. FTIR analyses were performed at room temperature within the wavenumber range of $400-1400 \mathrm{~cm}^{-1}$ by using diamond ATR with a resolution of $4 \mathrm{~cm}^{-1}$. Origin 2018 program was used to determine hidden bands in the spectrum.

Netzsch STA 449F3 simultaneous thermogravimetric analyze device was used in the determination of thermal properties. DSC measurements were made with approximately $50 \mathrm{mg}$ of powdered sample between the range of room temperature and $1000{ }^{\circ} \mathrm{C}$ with increments of 1 ${ }^{\circ} \mathrm{C}$. Glass transition, crystallization and melting temperatures were calculated from the obtained 
graphs with ONSET method (Fig. 3). In addition, thermal stabilities $(\Delta T)$ belonging to glasses were calculated with the following equation:

$$
\Delta T=T_{c}-T_{g}
$$

Here $T_{c}$ is the first crystallization temperature, $T_{g}$ is glass transition temperature.

\section{Results and Discussion}

\subsection{Density and molar volume}

Sample densities and molar volume values calculated with the help of Eqn. (1) are given in Table 1. In addition, sample codes and ratio of components within the glass can also be seen. As you can see in Fig. 2, density values of the samples decreased regularly from $3.392{\mathrm{~g} . \mathrm{cm}^{-3}}^{-3} 3.329$ g.cm ${ }^{-3}$ with increasing amount of $\mathrm{V}_{2} \mathrm{O}_{5}$. On the other hand, molar volume values increased from $22.910 \mathrm{~cm}^{3} \cdot \mathrm{mol}^{-1}$ to $24.289 \mathrm{~cm}^{3} \cdot \mathrm{mol}^{-1}$ almost linearly. $\mathrm{V}_{2} \mathrm{O}_{5}$ 's being a more complex molecule led to volume increase, in addition, since masses of shifting vanadium and zinc were close to each other, it resulted in decrease in the molar volume. Similar impact can also be found in the literature [54].

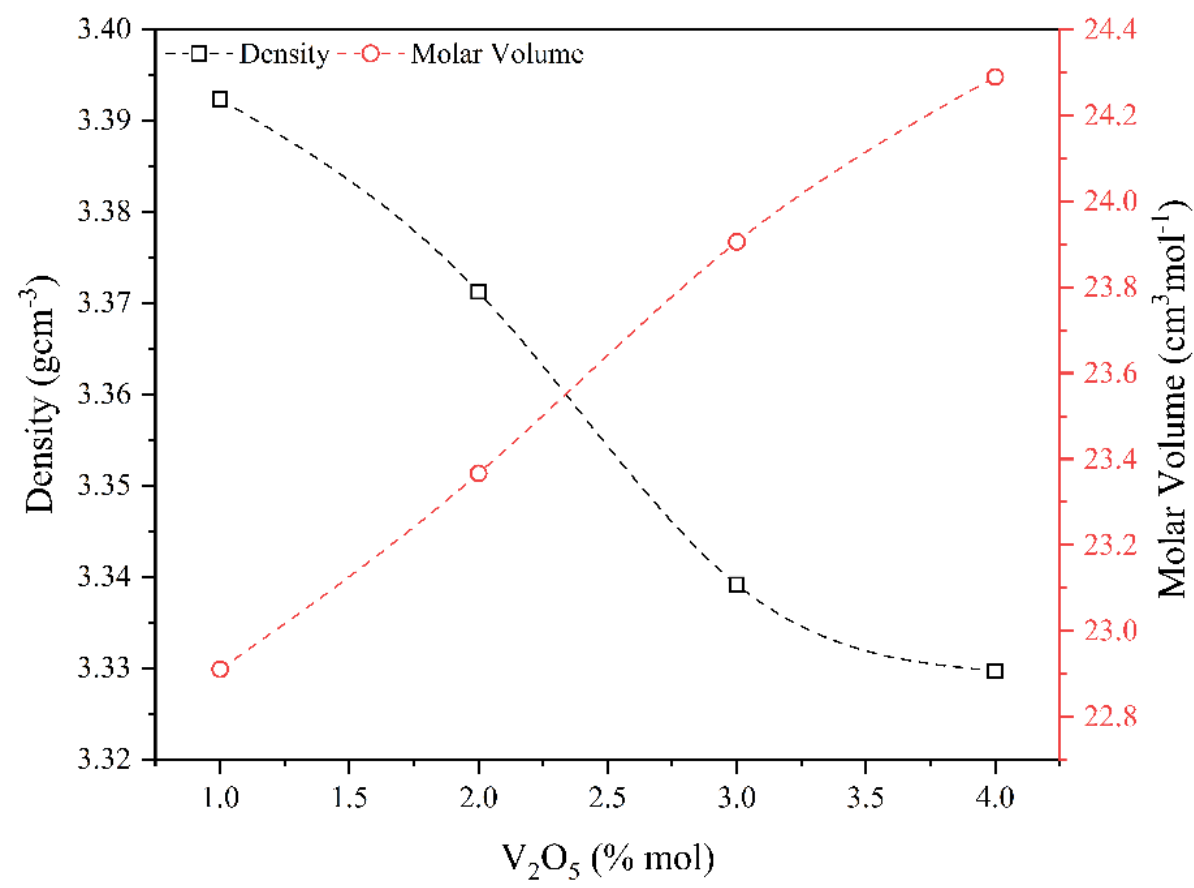

Figure 2: Change in density and molar volume values according to $\mathrm{V}_{2} \mathrm{O}_{5}$ concentration 
Table 1: Sample codes, \% compositions and calculated density and molar volume values of synthesized samples

\begin{tabular}{cccccc}
\hline Sample & $\mathbf{Z n O}$ & $\mathbf{B}_{\mathbf{2}} \mathbf{O}_{\mathbf{3}}$ & $\mathbf{V}_{\mathbf{2}} \mathbf{O}_{\mathbf{5}}$ & Density & Molar volume \\
\cline { 2 - 6 } Code & $\mathrm{mol} \%$ & $\mathrm{~mol} \%$ & $\mathrm{~mol} \%$ & $\mathrm{~g}^{-\mathrm{cm}^{-3}}( \pm 0.001)$ & $\mathrm{cm}^{3} \cdot \mathrm{mol}^{-1}( \pm 0.005)$ \\
\hline ZBV1 & 59.40 & 39.60 & 1.00 & 3.392 & 22.910 \\
ZBV2 & 58.80 & 39.20 & 2.00 & 3.371 & 23.366 \\
ZBV3 & 58.20 & 38.80 & 3.00 & 3.339 & 23.906 \\
ZBV4 & 57.60 & 38.40 & 4.00 & 3.329 & 24.289 \\
\hline
\end{tabular}

\subsection{Thermal properties}

DSC thermograms belonging to synthesized ZBV glass samples are given in Fig. 3, and their glass transition temperatures, crystallization and melting temperatures are given in Table 2. As it can be seen in DSC thermograms, curves belonging to 4 samples are almost identical in respect to their shapes. 3 ambiguous exothermic peaks in the shape of shoulders are followed by 1 endothermic peak. Glass transition temperatures can be seen within the range of $530-550{ }^{\circ} \mathrm{C}$ and glass transition temperature has decreased with increasing amount of $\mathrm{V}_{2} \mathrm{O}_{5}$. First crystallization temperature was around $740{ }^{\circ} \mathrm{C}$; the range of $818-833^{\circ} \mathrm{C}$ was the region of second crystallization temperature. When we have reviewed the literature, we can see that various crystalline phases are mentioned between glassy transition temperature and melting temperature in similar systems [55]. These are $\mathrm{Zn}_{3} \mathrm{~B}_{2} \mathrm{O}_{6}$ crystalline phase around $680{ }^{\circ} \mathrm{C}$ and $\mathrm{Zn}_{3} \mathrm{~V}_{2} \mathrm{O}_{8}$ crystalline phase around $700{ }^{\circ} \mathrm{C}$. In $\mathrm{Nb}_{2} \mathrm{O}_{5}$ doped zinc-borate glasses, $\mathrm{ZnNb}_{2} \mathrm{O}_{6}$ crystalline phase containing $\mathrm{Nb}$ is found around $740{ }^{\circ} \mathrm{C}$.

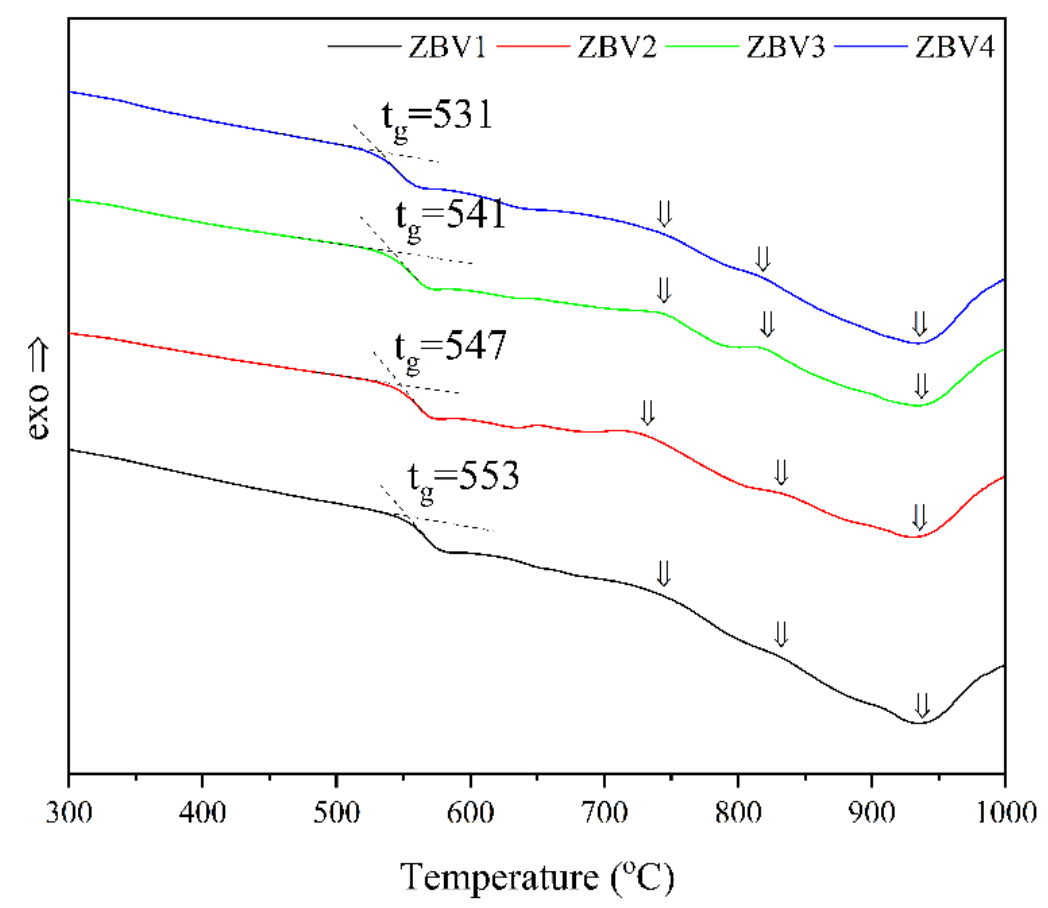

Figure 3: DSC thermograms belonging to samples 
In the light of all these data, we estimate that the peak that we have observed in the proximity of $740{ }^{\circ} \mathrm{C}$ belong to $\mathrm{Zn}_{3} \mathrm{~V}_{2} \mathrm{O}_{8}$ and $\mathrm{ZnV}_{2} \mathrm{O}_{6}$ crystalline phases in the glasses that we have synthesized. The second crystallization temperature decreased with increasing amount of $\mathrm{V}_{2} \mathrm{O}_{5}$. Melting temperatures belonging to were almost the same and around $935{ }^{\circ} \mathrm{C}$. Decrease in glass transition temperatures and crystallization temperatures remaining almost the same with increasing amount of $\mathrm{V}_{2} \mathrm{O}_{5}$ naturally resulted in increase in the thermal stability $(\Delta T)$. Glassy transition temperatures are reported to increase in tellurium and silicon-based glasses with the addition of $\mathrm{Nb}_{2} \mathrm{O}_{5}, \mathrm{~V}_{2} \mathrm{O}_{5}$ in increasing amounts. Decrease in glass transition temperatures of the samples in this study with increasing concentration of $\mathrm{V}_{2} \mathrm{O}_{5}$ can be explained with bond enthalpy. While B-O bond enthalpy was $809 \mathrm{kJmol}^{-1}$, V-O bond enthalpy was lower $\left(637 \mathrm{kJmol}^{-1}\right)$. Substituting O-B-O bonds with weaker O-V-O connections lowers activation energy for structural reorganizations. Accordingly, glass transition temperature decreases with increasing $\mathrm{V}_{2} \mathrm{O}_{5}$.

Table 2: Glass transition, crystallization, melting temperatures and thermal stabilities of synthesized ZBV glasses

\begin{tabular}{cccccc}
\hline Sample & $\boldsymbol{T}_{\boldsymbol{g}}$ & $\boldsymbol{T}_{\boldsymbol{c} \mathbf{1}}$ & $\boldsymbol{T}_{\boldsymbol{c} \mathbf{2}}$ & $\boldsymbol{T}_{\boldsymbol{m}}$ & $\boldsymbol{\Delta} \boldsymbol{T}$ \\
\cline { 2 - 6 } Code & $\left.\mathbf{(}^{\mathbf{C}} \mathbf{C}\right)( \pm 1)$ & $\left.\mathbf{(}^{\circ} \mathbf{C}\right)( \pm 1)$ & $\left({ }^{\circ} \mathbf{C}\right)( \pm 1)$ & $\left({ }^{\circ} \mathbf{C}\right)( \pm 1)$ & $\left({ }^{\circ} \mathbf{C}\right)( \pm 1.2)$ \\
\hline ZBV1 & 553 & 743 & 833 & 935 & 190 \\
ZBV2 & 547 & 730 & 831 & 933 & 183 \\
ZBV3 & 541 & 743 & 820 & 935 & 202 \\
ZBV4 & 531 & 743 & 818 & 935 & 212 \\
\hline
\end{tabular}

\subsection{Structural examination}

FTIR spectra are given all together in Fig. 4. In addition, basic structural units of boron and vanadium and their corresponding localizations in our synthesized glasses are also given within this figure. In Fig. 5, deconvolutions of FTIR spectra belonging to samples are given. FTIR spectra were examined in three basic regions.

The first region is the $400-800 \mathrm{~cm}^{-1}$ region. In this region, vibrations belonging to various connections can be seen. The second region is between $800-1200 \mathrm{~cm}^{-1}$ and mostly vibrations belonging to $\mathrm{BO}_{4}$ structural units of boron are observed in this region. The third region is the region around $1200-1500 \mathrm{~cm}^{-1}$ and mostly various vibrations corresponding to $\mathrm{BO}_{3}$ structural unit of boron can be seen in these regions. Except for boron that forms the glass network, vibrations corresponding to various states of zinc and vanadium found in the glass can also be observed within these regions (Table 3). 


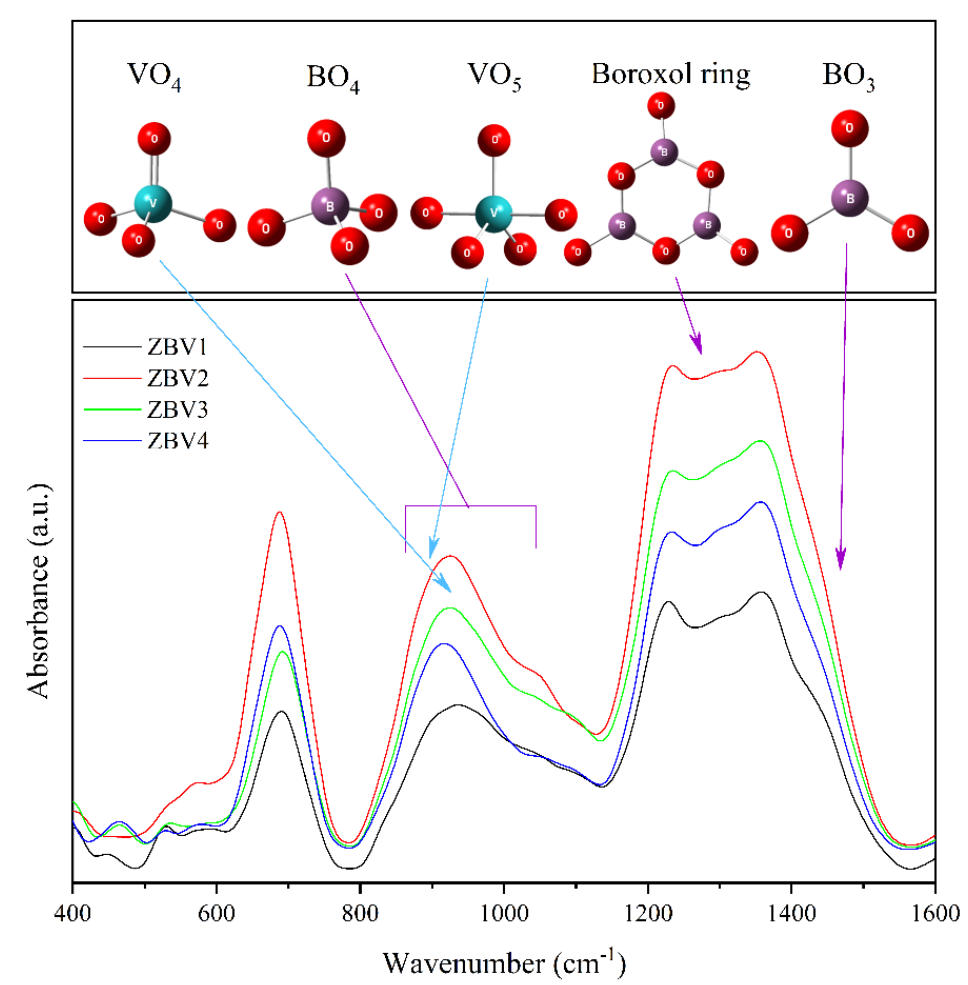

Figure 4: $400-1600 \mathrm{~cm}^{-1}$ region FTIR spectra and localizations of structural units belonging to ZBV samples

One or more intensive peaks can be seen in all regions. Bands found between $449-464 \mathrm{~cm}^{-}$ ${ }^{1}$ within the first regions are known to belong to the vibrations in the $\mathrm{ZnO}_{4}$ unit. Apart from this, $\mathrm{O}-\mathrm{V}$ angular vibration is reported to correspond to $526-534 \mathrm{~cm}^{-1}, \mathrm{Zn}-\mathrm{O}$ stretching vibration correspond to $575-595 \mathrm{~cm}^{-1}$, and B-O-B connection vibration correspond to the bands within 676$730 \mathrm{~cm}^{-1}$. The most intense peak in this region belongs to the band around $680 \mathrm{~cm}^{-1}$ and shows the abundance of B-O-B connections within the structure.

Bands belonging to $\mathrm{B}-\mathrm{O}$ stretching vibrations belonging to $\mathrm{BO}_{4}$ unit in the second region are found within the ranges of $873-886 \mathrm{~cm}^{-1}, 930-939 \mathrm{~cm}^{-1}, 1042-1055 \mathrm{~cm}^{-1}$. It is also known in $\mathrm{V}_{2} \mathrm{O}_{5}$ containing structures that the presence of bands belonging to the vibrations of $\mathrm{VO}_{5}$ and $\mathrm{VO}_{4}$ structural units are also found within the regions of $873-886 \mathrm{~cm}^{-1}$ and $930-939 \mathrm{~cm}^{-1}$ where B-O stretching vibrations have been encountered. Intensity of bands belonging to B-O vibration is known to decrease with increasing concentration of $\mathrm{V}_{2} \mathrm{O}_{5}$ in penta- and diborate groups within the range of $1103-1114 \mathrm{~cm}^{-1}$; however, the intensity of the band belonging to B-O vibration in meta- and orthoborate groups increases within the range of $1222-1231 \mathrm{~cm}^{-1}$ found in the third region. 

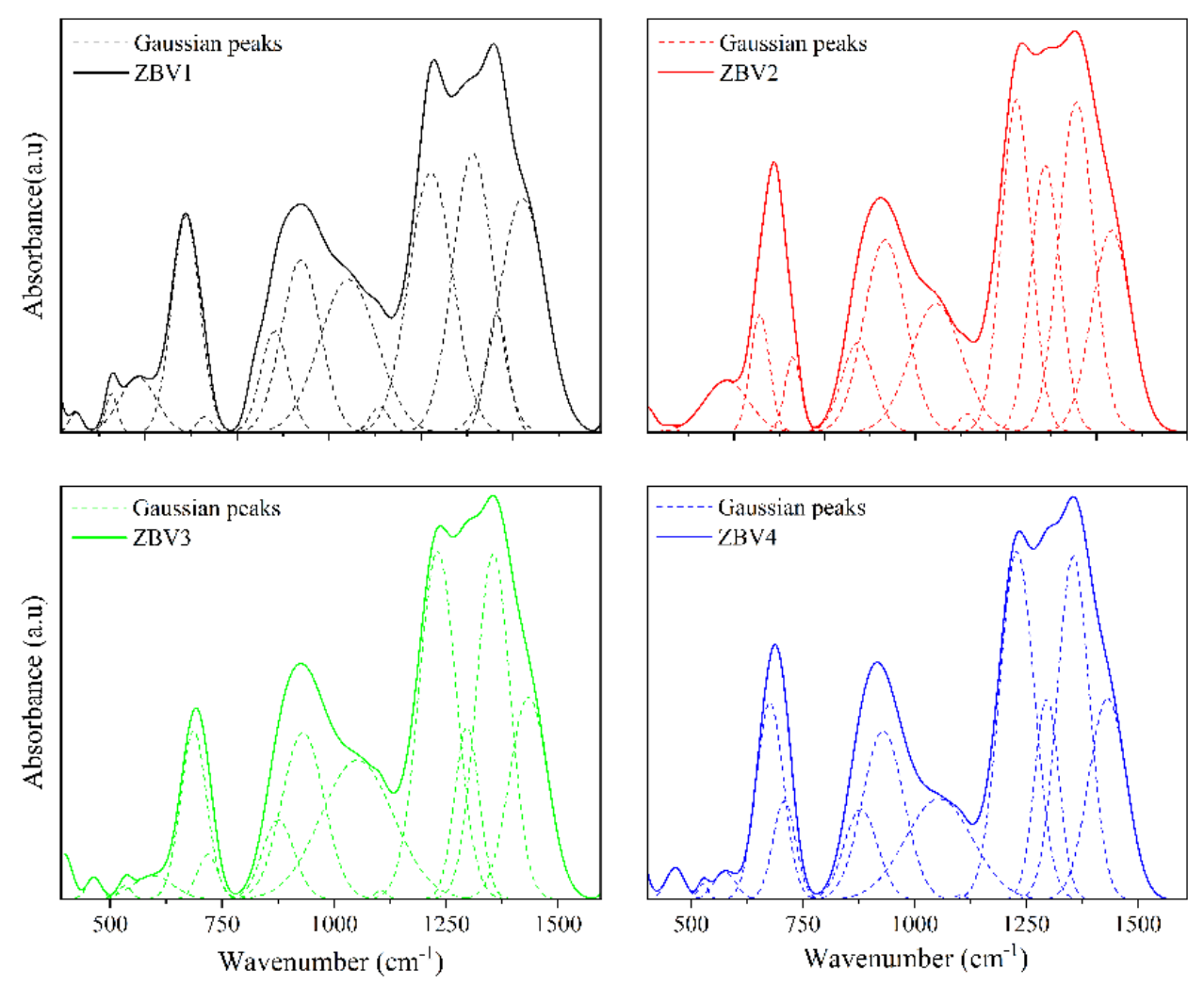

Figure 5: Deconvolution of FTIR spectra belonging to ZBV samples. Straight lines show the FTIR spectra belonging to samples and dashed lines show the Gaussian bands obtained from deconvolution

Table 3: Bands belonging to ZBV samples and corresponding vibrations

\begin{tabular}{|c|c|c|c|c|c|}
\hline ZBV1 & ZBV2 & ZBV3 & ZBV4 & Vibrations & References \\
\hline$\left(\mathrm{cm}^{-1}\right)$ & $\left(\mathrm{cm}^{-1}\right)$ & $\left(\mathrm{cm}^{-1}\right)$ & $\left(\mathrm{cm}^{-1}\right)$ & & \\
\hline 449 & 458 & 464 & 464 & $\mathrm{Zn}-\mathrm{O}$ vibration in $\mathrm{ZnO}_{4}$ structure & {$[56]$} \\
\hline 527 & - & 534 & 526 & $\mathrm{O}-\mathrm{V}$ angular deformation vibration & [57] \\
\hline 584 & 582 & 595 & 575 & $\mathrm{Zn}-\mathrm{O}$ stretching vibration & {$[58]$} \\
\hline 688 & 693 & 686 & 676 & B-O-B connection vibration & [59] \\
\hline 729 & 730 & 718 & 708 & B-O-B connection vibration & {$[60]$} \\
\hline 882 & 873 & 876 & 880 & $\begin{array}{l}>\text { B-O stretching vib. in } \mathrm{BO}_{4} \text { unit } \\
>\text { Stretching vib. of } \mathrm{VO}_{5}\end{array}$ & [59] \\
\hline 939 & 933 & 931 & 930 & $\begin{array}{l}>\text { B-O stretching vibration in } \mathrm{BO}_{4} \text { unit } \\
>\text { Stretching vib. of } \mathrm{VO}_{2} \text { in } \mathrm{VO}_{4} \text { unit }\end{array}$ & [59] \\
\hline 1042 & 1046 & 1052 & 1055 & Vibration belonging to tetrahedral $\mathrm{BO}_{4}$ unit & {$[61]$} \\
\hline 1110 & 1114 & 1104 & 1103 & $\mathrm{~B}-\mathrm{O}$ vibration in penta- and di- borate groups & [59] \\
\hline 1222 & 1223 & 1231 & 1229 & B-O vibration in meta- and ortho- borate groups & [59] \\
\hline 1313 & 1287 & 1297 & 1296 & B-O vibration in boroxol ring & {$[58]$} \\
\hline 1365 & 1355 & 1356 & 1356 & $\begin{array}{l}>\mathrm{B}-\mathrm{O}-\mathrm{B} \text { connection vibration } \\
>\mathrm{Zn}-\mathrm{O}-\mathrm{B} \text { connection vibration }\end{array}$ & $\begin{array}{l}{[10]} \\
{[59]}\end{array}$ \\
\hline 1421 & 1433 & 1435 & 1432 & NBO B-O- stretching vibration in $\mathrm{BO}_{3}$ unit & {$[62]$} \\
\hline
\end{tabular}

In the third region, it was observed that bands belonging to boroxol ring and $\mathrm{BO}_{3}$ structure of boron was prominently found; nevertheless, bands belonging to B-O-B and Zn-O-B vibrations 
were also present. Bands within the range of $1287-1365 \mathrm{~cm}^{-1}$ belong to B-O in the boroxol ring, bands in the 1421-1435 $\mathrm{cm}^{-1}$ regions belong to $\mathrm{B}-\mathrm{O}$ - vibrations found in the $\mathrm{BO}_{3}$ unit having nonbridging oxygen (NBO). Although the band around $1355 \mathrm{~cm}^{-1}$ is known to belong to B-O-B connection vibration, it was reported in some studies that it corresponded to $\mathrm{Zn}-\mathrm{B}-\mathrm{O}$ connection vibration in similar structures.

\subsection{Optical properties}

Transmittance spectra obtained with scanning $1.5 \mathrm{~cm}$ piece of the surface belonging to the synthesized glassed are given in Fig. 6 and transmittance and absorption spectra obtained from a single point of the samples are given in Fig. 7. Transmittance spectra obtained from surface scanning spectrophotometer were obtained from 16 different regions with intervals of $1 \mathrm{~mm}$ each. When compared with the transmittance curves found in these spectra, which were used to determine the uniformity of the samples, transmittance was seen to be similar in spectrum of every sample. This proves that a significant aggregation or bubble was not present and the samples had uniform distribution.
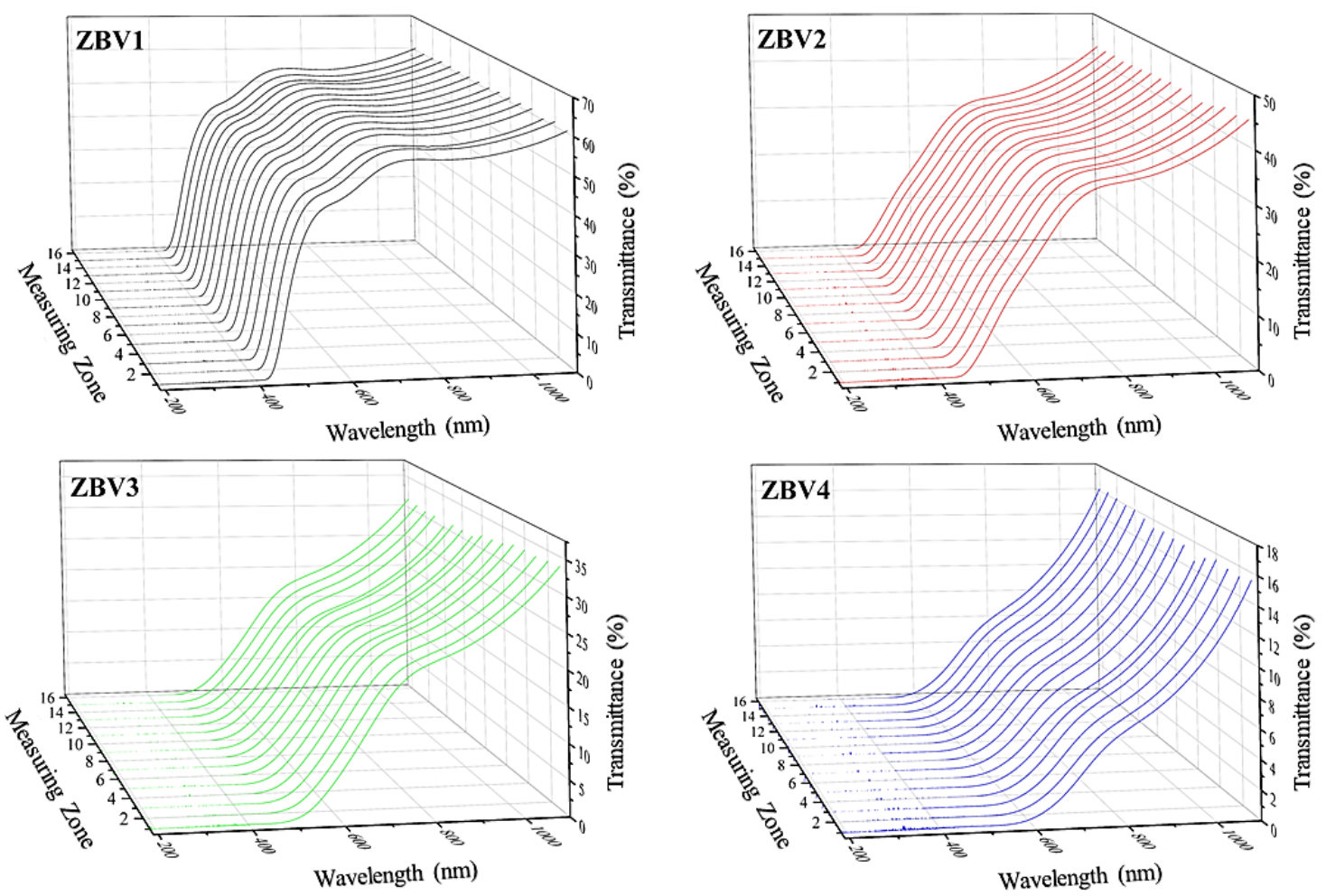

Figure 6: Transmittance spectra obtained by scanning approximately $1.5 \mathrm{~cm}$ regions of the samples

In Fig. 7, in which data obtained from a single point were evaluated collectively, absorption edges of spectra belonging to transmittance and absorption were observed to shift towards red (long wavelength) with increasing concentration of $\mathrm{V}_{2} \mathrm{O}_{5}$. Spectra shifted towards long 
wavelength for approximately for $25 \mathrm{~nm}$ each. Transmittance value decreased significantly. Switching oxygen bond in the glass network and change in the number of non-bridging oxygen (NBO) in the network also changes absorption properties [54]. Shifting of the absorption edge towards long wavelength with increasing amount of $\mathrm{V}_{2} \mathrm{O}_{5}$ and also decrease in optical band gaps might be explained with this change.

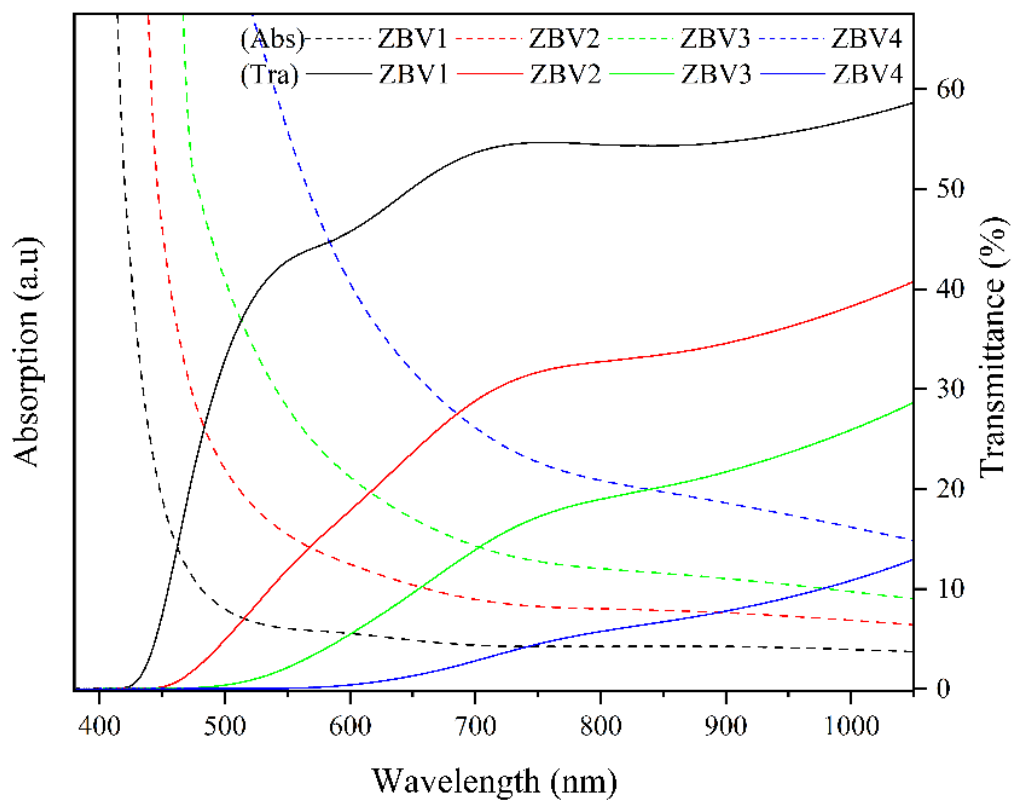

Figure 7: Absorption-transmittance spectra of ZBV samples against wavelength

Optical band gaps of synthesized glass samples were calculated by using absorption spectrum for indirect transitions. Absorption coefficient is given according to Lambert - Beer Bouguer Law [63].

$$
\alpha=0.202\left(\frac{A}{d}\right)
$$

Here, $A$ is the absorbance, $d$ is the thickness of the sample. Photon energies belonging to wavelengths corresponding to linear part of the absorption spectrum were calculated with the help of the following equation [63]:

$$
E=h v
$$

Moreover, $(\alpha h v)^{1 / 2} \sim h v$ graphics were plotted for indirect transitions for each sample. In these equations, $\alpha$ is the absorption coefficient, $h$ is the Planck constant, $v$ is photon frequency and in addition, $h v$ is the photon energy. 
From the value of this line passing through the linear part of this plotted Tauc curve (Fig. 8) corresponding to $(\alpha h v)^{1 / 2}=0$ optical band gap belonging to the sample is found. Optical band gaps of $\mathrm{V}_{2} \mathrm{O}_{5}$ doped glasses varied between $2.55 \mathrm{eV}$ and $1.24 \mathrm{eV}$. Increase in $\mathrm{V}_{2} \mathrm{O}_{5}$ regularly reduced the optical band gap.

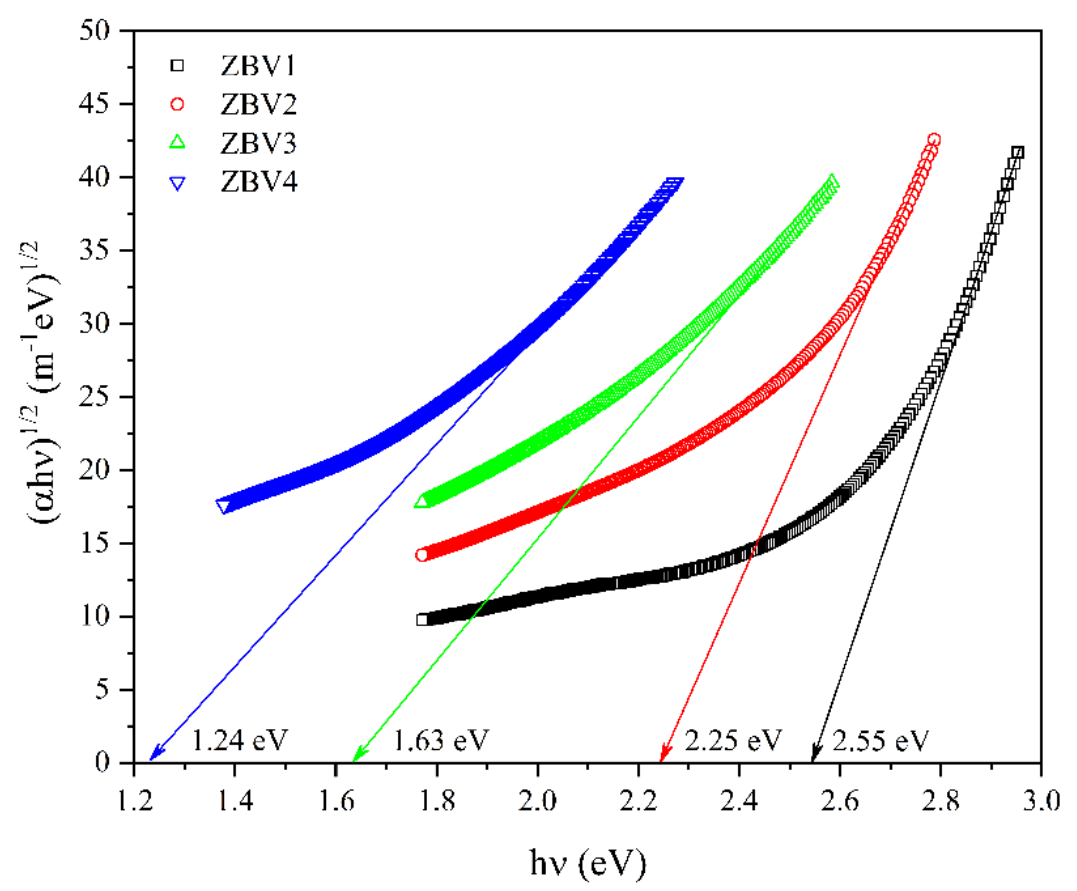

Figure 8: Tauc Plots belonging to ZBV samples

With the curve of the absorption edge in the semi-logarithmic plot (Fig. 9),

$$
\Delta E=\left[\frac{d(\ln \alpha)}{d(h v)}\right]^{-1}
$$

Urbach Energies were calculated [63]. Fitting values of lines plotted from the straight part of the absorption edge were $\mathrm{R}^{2}>0.99$. Here, $\Delta E$ is named as Urbach energy, $\alpha$ is absorption coefficient and $h v$ as photon energy.

A stable increase was observed in Urbach energies due to increase in $\mathrm{V}_{2} \mathrm{O}_{5}$ concentration. Urbach energy was calculated between the range of $0.246 \mathrm{eV}$ and $0.630 \mathrm{eV}$. Urbach energy belonging to non-doped, pure $60 \% \mathrm{ZnO}-40 \% \mathrm{~B}_{2} \mathrm{O}_{3}$ glass was calculated within the range of 0.17 $\mathrm{eV}$ [54]. This result is in line with the values that have been obtained in this study. Low Urbach energy value shows us that the structure of the synthesize glass structure is uniform and stable. Increase in $\mathrm{V}_{2} \mathrm{O}_{5}$ concentration in the glass network shows that the structure has become irregular and unstable [64]. 
Table 4: Optical band gap, Urbach energies and refractive indices of synthesized ZBV glasses

\begin{tabular}{cccc}
\hline Sample & Optical band gap & Urbach energies & Refractive index \\
\cline { 2 - 4 } Code & $(\mathrm{eV})$ & $(\mathrm{eV})$ & \\
\hline ZBV1 & 2.55 & 0.246 & 2.530 \\
ZBV2 & 2.25 & 0.346 & 2.635 \\
ZBV3 & 1.63 & 0.630 & 2.917 \\
ZBV4 & 1.24 & 0.630 & 3.170 \\
\hline
\end{tabular}

Refractive index is an important data for materials that are considered to be used in optoelectronics. Refractive indices were determined with the help of Eqn. (3) using optical band gaps data within the region corresponding to the absorption edge. Refractive indices of the samples were calculated within the range of 2.530-3.170. As it can be seen in Table 4, refractive index increased in direct proportion to increase in $\mathrm{V}_{2} \mathrm{O}_{5}$.
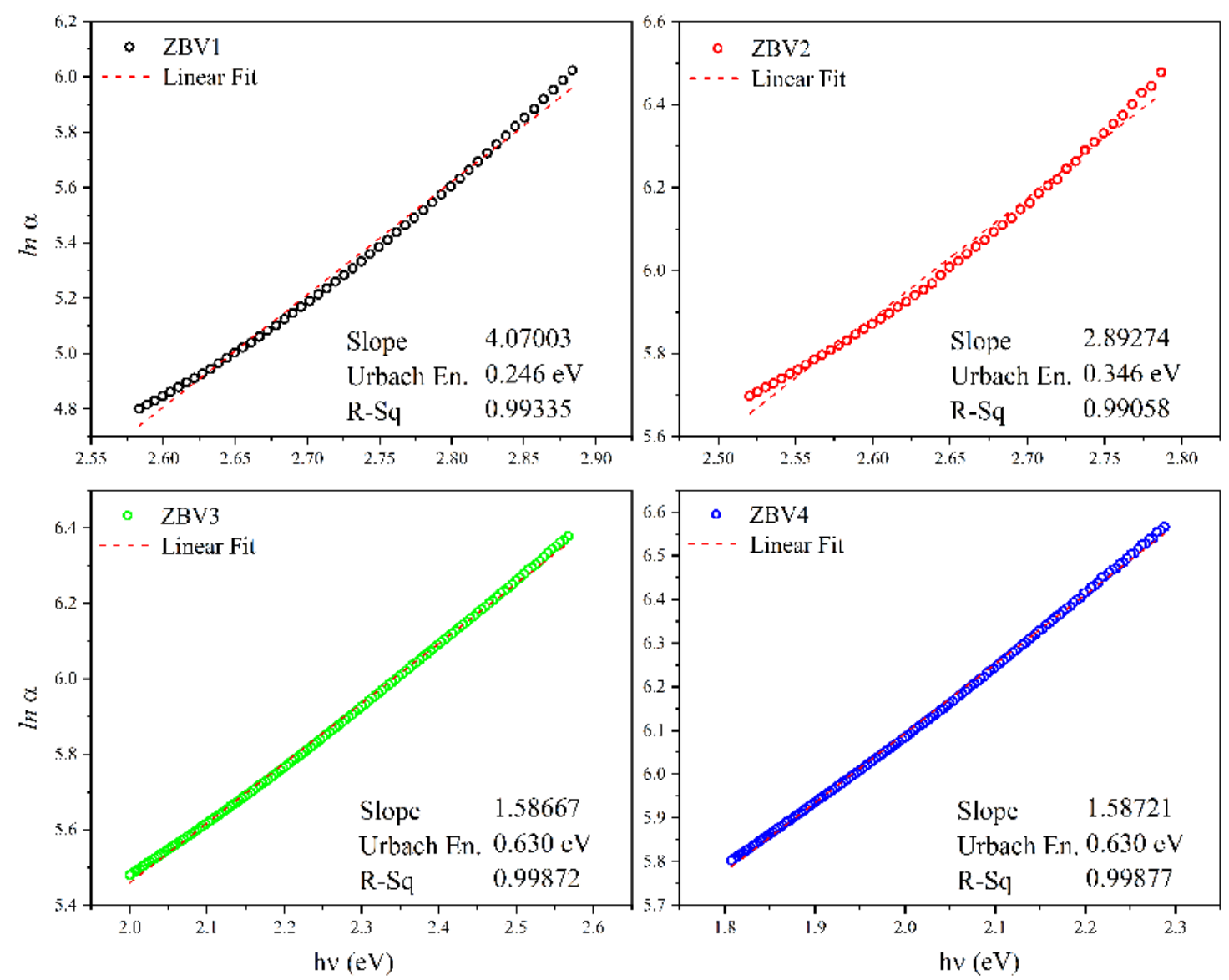

Figure 9: Urbach Energies, slopes, and $\mathrm{R}^{2}$ fitting values of ZBV samples

\section{Conclusions}

Ternary zinc borate oxide glass samples doped with different ratios of $\mathrm{V}_{2} \mathrm{O}_{5}$ were synthesized successfully. Physical, structural, thermal, and optical characterization of these 
synthesized samples were performed. Structural units were determined with FTIR. $\mathrm{B}_{2} \mathrm{O}_{3}$ was found to be present in the glass network in the structure of the boroxol ring, planar $\mathrm{BO}_{3}$, tetrahedral $\mathrm{BO}_{4} . \mathrm{ZnO}$, acting as the organizer with its low concentration in the structures in which it is found, was determined to be present in the samples of this study in tetrahedral $\mathrm{ZnO}_{4}$ and octahedral $\mathrm{ZnO}_{6}$ structural units; and it was concluded that it might be present in the glass network as a glass former. Vanadium is present in the glass network with $\mathrm{VO}_{4}$ and $\mathrm{VO}_{5}$ structural unit. Increase in $\mathrm{VO}_{5}$ shifted the absorption edge significantly towards the red region and correspondingly decrease optical band gap to $1.24 \mathrm{eV}$ from $2.55 \mathrm{eV}$ and as expected, led to increase in Urbach energy. Increase in Urbach energy proves that $\mathrm{V}_{2} \mathrm{O}_{5}$ renders the structure nonuniform and unstable. As a result of thermal characterization, $\mathrm{V}_{2} \mathrm{O}_{5}$ increase was found to decrease glass transition temperature to $531{ }^{\circ} \mathrm{C}$ from $553{ }^{\circ} \mathrm{C}$. While density decreased with increasing amount of $\mathrm{V}_{2} \mathrm{O}_{5}$, molar volume values demonstrated increase, as well. Similar to molar volume, refractive index also increased. High refractive indices increasing to 3.170 from 2.530 showed that synthesized glasses are potential materials that could be used in optical system requiring high refractive index. These glasses, considered to find application in many fields of optoelectronics also have the property of being novel materials for solar energy systems due to their semiconducting properties.

\section{References}

[1] Kılıç, G., Değişik bileşimli camların hazırlanmast, fiziksel ve optik özelliklerinin incelenmesi. PhD Thesis, Eskişehir Osmangazi University, Eskişehir, Turkey, 2006.

[2] Rao, R.B., Veeraiah, N., Study on some physical properties of $\mathrm{Li}_{2} \mathrm{O}-\mathrm{MO}-\mathrm{B}_{2} \mathrm{O}_{3}: \mathrm{V}_{2} \mathrm{O}_{5}$ glasses, Physica B: Condensed Matter, 348, 256-271, 2004.

[3] El-Batal, H.A.R., Ezz-El-Din, F.M., Interaction of $\gamma$-rays with Some Alkali Alkaline Earth Borate Glasses Containing Chromium, Journal of the American Ceramic Society, 76, 523, 1993.

[4] Abdel-Baki, M., El-Diasty, F., Role of oxygen on the optical properties of borate glass doped with ZnO, Journal of Solid State Chemistry, 184, 2762-2769, 2011.

[5] El-Falaky, G.E., Gaafar, M.S., Abd El-Aal, N.S., Ultrasonic relaxation in Zinc-Borate glasses, Current Applied Physics, 12, 589-596, 2012.

[6] Sumalatha, B., Omkaram, I., Rao, T.R., Raju, Ch. L., Alkaline earth zinc borate glasses doped with $\mathrm{Cu}^{2+}$ ions studied by EPR, optical and IR techniques, Journal of Non-Crystalline Solids, 357, 3143-3152, 2011.

[7] Kumar, R.R., Bhatnagar, A.K., Rao, J.L., EPR of vanadyl ions in alkali lead borate glasses, Materials Letters, 57, 178-182, 2002.

[8] Rada, M., Rada, S., Pascuta, P., Culea, E., Structural properties of molybdenum-leadborate glasses, Spectrochimica Acta A, 77, 832-837, 2010. 
[9] Rao, T.R., Reddy, Ch.V., Krishna, Ch.R., Thampy, U.S.U., Raju, R.R., Rao, S., Ravikumar, R.V.S.S.N., Correlation between physical and structural properties of $\mathrm{Co}^{2+}$ doped mixed alkali zinc borate glasses, Journal of Non-Crystalline Solids, 357, 3373-3380, 2011.

[10] Singh, G.P., Kaur, S., Kaur, P., Kumar, S., Singh, D.P., Structural and optical properties of $\mathrm{WO}_{3}-\mathrm{ZnO}-\mathrm{PbO}-\mathrm{B}_{2} \mathrm{O}_{3}$ glasses, Physica B: Condensed Matter, 406, 1890-1893, 2011.

[11] He, F., Wang, J., Deng, D., Effect of $\mathrm{Bi}_{2} \mathrm{O}_{3}$ on structure and wetting studies of $\mathrm{Bi}_{2} \mathrm{O}_{3^{-}}$ $\mathrm{ZnO}-\mathrm{B}_{2} \mathrm{O}_{3}$ glasses, Journal of Alloys and Compounds, 509, 6332-6336, 2011.

[12] Lian, Z., Wang, J., Lv, Y., Wang, S., The reduction of $E u^{3+}$ to $E u^{2+}$ in air and luminescence properties of $\mathrm{Eu}^{2+}$ activated $\mathrm{ZnO}-\mathrm{B}_{2} \mathrm{O}_{3}-\mathrm{P}_{2} \mathrm{O}_{5}$ glasses, Journal of Alloys and Compounds, 430, 257-261, 2007.

[13] Saritha, D., Markandeya, Y., Salagram, M., Vithal, M., Effect of $\mathrm{Bi}_{2} \mathrm{O}_{3}$ on physical, optical and structural studies of $\mathrm{ZnO}-\mathrm{Bi}_{2} \mathrm{O}_{3}-\mathrm{B}_{2} \mathrm{O}_{3}$ glasses, Journal of Non-Crystalline Solids, 354, 5573-5579, 2008.

[14] Li, S., Chen, P., Li, Y., Structural and physical properties in the system $\mathrm{ZnO}-\mathrm{B}_{2} \mathrm{O}_{3^{-}}$ $\mathrm{P}_{2} \mathrm{O}_{5}-\mathrm{R}_{n} \mathrm{O}_{m}$, Physica B: Condensed Matter, 405, 4845-4850, 2010.

[15] Aleksandrov, L., Komatsu, Iordanova, R., Dimitriev, Y., Structure study of $\mathrm{MoO}_{3^{-}}$ $\mathrm{ZnO}-\mathrm{B}_{2} \mathrm{O}_{3}$ glasses by Raman spectroscopy and formation of $\mathrm{ZnMoO}_{4}$ nanocrystals, Optical Materials, 33, 839-845, 2011.

[16] Lakshminarayana, G., Buddhudu, S., Spectral analysis of $\mathrm{Sm}^{3+}$ and $\mathrm{Dy}^{3+}: \mathrm{B}_{2} \mathrm{O}_{3}-\mathrm{ZnO}-$ PbO glasses, Physica B: Condensed Matter, 373, 100-106, 2006.

[17] Singh, H., Singh, K., Gerward, L., Singh, K., $\mathrm{ZnO}-\mathrm{PbO}-\mathrm{B}_{2} \mathrm{O}_{3}$ glasses as gamma-ray shielding materials, Nuclear Instruments and Methods in Physics Research B, 207, 257-262, 2003.

[18] Thulasiramudu, A., Buddhudu, S., Optical characterization of $\mathrm{Sm}^{3+}$ and $\mathrm{Dy}^{3+}: \mathrm{ZnO}-$ $\mathrm{PbO}-\mathrm{B}_{2} \mathrm{O}_{3}$ glasses, Spectrochimica Acta A, 67, 802-807, 2007.

[19] Mosner, P., Vosejpkova, K., Koudelka, L., Montagne, L., Revel, B., Structure and properties of $\mathrm{ZnO}-\mathrm{B}_{2} \mathrm{O}_{3}-\mathrm{P}_{2} \mathrm{O}_{5}-\mathrm{TeO}_{2}$ glasses, Materials Chemistry and Physics, 124, 732-737, 2010.

[20] Wu, J., Xie, C., Hu, J., Zeng, D., Wang, A., Microstructure and electrical characteristics of $\mathrm{ZnO}-\mathrm{B}_{2} \mathrm{O}_{3}-\mathrm{PbO}-\mathrm{V}_{2} \mathrm{O}_{5}-\mathrm{MnO}_{2}$ ceramics prepared from $\mathrm{ZnO}$ nanopowders, Journal of the European Ceramic Society, 24, 3635-3641, 2004.

[21] Bale, S., Rahman. S., Electrical conductivity studies of $\mathrm{Bi}_{2} \mathrm{O}_{3}-\mathrm{Li}_{2} \mathrm{O}-\mathrm{ZnO}-\mathrm{B}_{2} \mathrm{O}_{3}$ glasses, Materials Research Bulletin, 47, 1153-1157, 2012.

[22] Ji, L.N., Li, J.B., Liang, J.K., Sun, B.J., Liu, Y.H., Phase relations and flux research for $\mathrm{ZnO}$ crystal growth in the $\mathrm{ZnO}-\mathrm{B}_{2} \mathrm{O}_{3}-\mathrm{P}_{2} \mathrm{O}_{5}$ system, Journal of Alloys and Compounds, 459, 481-486, 2008.

[23] Hu, Y., Wei, D., Fu, Q., Zhao, J., Zhou, D., Preparation and microwave dielectric properties of $3 \mathrm{ZnO} \cdot \mathrm{B}_{2} \mathrm{O}_{3}$ ceramics with low sintering temperature, Journal of the European Ceramic Society, 32, 521-524, 2012.

[24] Raju, G.N., Reddy, M.S., Sudhakar, K.S.V., Spectroscopic properties of copper ions in $\mathrm{ZnO}-\mathrm{ZnF}_{2}-\mathrm{B}_{2} \mathrm{O}_{3}$ glasses, Optical Materials, 29, 1467-1474, 2007.

[25] Kim, D.N., Lee, J.Y., Huh, J.S., Thermal and electrical properties of $\mathrm{BaO}-\mathrm{B}_{2} \mathrm{O}_{3}-\mathrm{ZnO}$ glasses, Journal of Non-Crystalline Solids, 306, 70-75, 2002.

[26] Masuda, H., Kimura, R., Sakamoto, N., Properties and Structure of Glasses in the System $\mathrm{BaO}-\mathrm{B}_{2} \mathrm{O}_{3}-\mathrm{ZnO}$, Journal of the Japan Institute of Metals, 63, 284, 1999. 
[27] Kundu, V., Dhiman, R.L., Goyal, D.R., Maan, A.S., Physical and electrical properties of semiconducting $\mathrm{Fe}_{2} \mathrm{O}_{3}-\mathrm{V}_{2} \mathrm{O}_{5}-\mathrm{B}_{2} \mathrm{O}_{3}$ glasses, Journal of Optoelectronics and Advanced Materials, 2(7), 428-432, 2008.

[28] Saritha, D., Markandeya, Y., Salagram, M., Vithal, M., Effect of $\mathrm{Bi}_{2} \mathrm{O}_{3}$ on physical, optical and structural studies of $\mathrm{ZnO}-\mathrm{Bi}_{2} \mathrm{O}_{3}-\mathrm{B}_{2} \mathrm{O}_{3}$ glasses, Journal of Non-Crystalline Solids, 354, 5573-5579, 2008.

[29] Toderaş, M., Filip, S., Ardelean, I., Structural study of the $\mathrm{Fe}_{2} \mathrm{O}_{3}-\mathrm{B}_{2} \mathrm{O}_{3}-\mathrm{BaO}$ glass system by FTIR spectroscopy, Journal of Optoelectronics and Advanced Materials, 3(8), 11211123, 2006.

[30] Schwarz, J., Ticha, H., Some optical properties of $\mathrm{BaO}-\mathrm{PbO}-\mathrm{B}_{2} \mathrm{O}_{3}$ glasses, Journal of Optoelectronics and Advanced Materials, 5(1), 69-74, 2003.

[31] Nagaraja, N., Sankarappa, T., Kumar, M.P., Electrical conductivity studies in single and mixed alkali doped cobalt-borate glasses, Journal of Non-Crystalline Solids, 354, 15031508, 2008.

[32] Chaudhry, M.A., Altaf, M., Optical absorption studies of sodium cadmium phosphate glasses, Materials Letters, 34, 213-216, 1998.

[33] Al-Hajry, A., Al-Shahran, A., El-Desoky, M.M., Structural and other physical properties of barium vanadate glasses, Materials Chemistry and Physics, 95, 300-306, 2006.

[34] Sharma, B.I., Robi, P.S., Srinivasan, A., Microhardness of ternary vanadium pentoxide glasses, Materials Letters, 57, 3504-3507, 2003.

[35] Ghosh, A., Bhattacharya, S., Ghosh, A., Optical and other structural properties of some zinc vanadate semiconducting glasses, Journal of Alloys and Compounds, 490, 480-483, 2010 .

[36] Tawaki, D.M., Adlan, M.J.B., Abdullah, M.J., DC electrical conductivity of semiconducting cobalt-phosphate glasses, Journal of Non-Crystalline Solids, 357, 2152-2155, 2011.

[37] Mandal, S., Ghosh, A., Electrical properties of lead vanadate glasses, Physical Review B: Condensed Matter and Materials Physics, 49, 3131, 1994.

[38] Rao, R.B., Veeraiah, N., Study on some physical properties of $\mathrm{Li}_{2} \mathrm{O}-\mathrm{MO}-\mathrm{B}_{2} \mathrm{O}_{3}: \mathrm{V}_{2} \mathrm{O}_{5}$ glasses, Physica B: Condensed Matter, 348, 256-271, 2004.

[39] Mott, N.F., Conduction in glasses containing transition metal ions, Journal of NonCrystalline Solids, 1, 1-17, 1968.

[40] Austin, G., Mott, N.F., Polarons in crystalline and non-crystalline materials, Advances in Physics, 18, 41-102, 1969.

[41] Sen, S., Ghosh, A., Structure and other physical properties of magnesium vanadate glasses, Journal of Non-Crystalline Solids, 258, 29-33, 1999.

[42] Moustafa, Y.M., El-Damrawi, G., Meikhail, M.S., Effect of Vanadium oxide on the structure and properties of lithium borate glasses, Mans Science Bulletin C, 20, 71, 1993.

[43] El-Damrawi, G., Moustafa, Y.M., Meikhail, M.S., Phase separation and NMR studies on sodium boro-silicate glasses containing $\mathrm{V}_{2} \mathrm{O}_{5}$, Mans Science Bulletin C, 20, 83, 1993.

[44] Singh, K., Ratnam, J.S., Electrical conductivity of the $\mathrm{Li}_{2} \mathrm{O}_{-} \mathrm{B}_{2} \mathrm{O}_{3}$ system with $\mathrm{V}_{2} \mathrm{O}_{5}$, Solid State Ionics, 31, 221-226, 1988. 
[45] Mekki, A., Khattak, G.D., Holland, D., Chinkhota, M., Wenger, L.E., Structure and magnetic properties of vanadium-sodium silicate glasses, Journal of Non-Crystalline Solids, 318 , 193-201, 2003.

[46] Ebendorff-Heidepriem, H., Riziotis, C., Taylor, E.R., Novel photosensitive glasses, Glass Science and Technology, 75, 54, 2002.

[47] Ghosh, A., Transport properties of vanadium germanate glassy semiconductors, Physical Review B: Condensed Matter and Materials Physics, 42, 5665, 1990.

[48] Sudarsan, V., Kulshreshtha, S.K., Study of structural aspects of $\mathrm{V}_{2} \mathrm{O}_{5}-\mathrm{P}_{2} \mathrm{O}_{5}-\mathrm{B}_{2} \mathrm{O}_{3}$ glasses, Journal of Non-Crystalline Solids, 258, 20-28, 1999.

[49] Ezz-Eldin, F.M., Radiation effects on some physical and thermal properties of $\mathrm{V}_{2} \mathrm{O}_{5}-$ $\mathrm{P}_{2} \mathrm{O}_{5}$ glasses, Nuclear Instruments and Methods in Physics Research B, 159, 166-175, 1999.

[50] Sindhu, S., Sanghi, S., Agarwal, A., Kishore, N., Seth, V.P., Effect of $V_{2} \mathrm{O}_{5}$ on structure and electrical properties of zinc borate glasses, Journal of Alloys and Compounds, 428, 206-213, 2007.

[51] Li, H., Lin, H., Chen, W., Luo, L., IR and Raman investigation on the structure of $(100-x)\left[0.33 \mathrm{~B}_{2} \mathrm{O}_{3}-0.67 \mathrm{ZnO}\right]-\mathrm{xV}_{2} \mathrm{O}_{5}$ glasses, Journal of Non-Crystalline Solids, 352, 3069-3073, 2006.

[52] Elkhoshkhany, N., El-Mallawany, R., Syala, E., Mechanical and thermal properties of $\mathrm{TeO}_{2}-\mathrm{Bi}_{2} \mathrm{O}_{3}-\mathrm{V}_{2} \mathrm{O}_{5}-\mathrm{Na}_{2} \mathrm{O}-\mathrm{TiO}_{2}$ glass system, Ceramics International, 42(16), 19218-19224, 2016.

[53] Dimitrov, V., Sakka, S., Linear and nonlinear optical properties of simple oxides. II, Journal of Applied Physics, 79, 1741-1745, 1996.

[54] Altaf, M., Chaudhry, M.A., Zahid, M., Study of optical band gap of zinc-borate glasses, Journal of Research (Science), 14(2), 253-259, 2003.

[55] Kaur, A., Khanna, A., Sathe, V.G., Gonzalez, F., Ortiz, B., Optical, thermal, and structural properties of $\mathrm{Nb}_{2} \mathrm{O}_{5}-\mathrm{TeO}_{2}$ and $\mathrm{WO}_{3}-\mathrm{TeO}_{2}$ glasses, Phase Transitions, 86(6), 598-619, 2013.

[56] Mohamed, N.B., Yahya, A.K., Deni, M.S.M., Mohamed, S.N., Halimah, M.K., Sidek, H.A.A., Effects of concurrent $\mathrm{TeO}_{2}$ reduction and $\mathrm{ZnO}$ addition on elastic and structural properties of $(90-x) \mathrm{TeO}_{2}-10 \mathrm{Nb}_{2} \mathrm{O}_{5}-(x) \mathrm{ZnO}$ glass, Journal of Non-Crystalline Solids, 356, 16261630, 2010.

[57] Laila, S., Supardan, S.N., Yahya, A.K., Effect of $\mathrm{ZnO}$ addition and concurrent reduction of $\mathrm{V}_{2} \mathrm{O}_{5}$ on network formation and elastic properties of lead vanadate $(55-x) \mathrm{V}_{2} \mathrm{O}_{5}-$ 45PbO-(x)ZnO glass system, Journal of Non-Crystalline Solids, 367, 14-22, 2013.

[58] Pascuta, P., Vladescu, A., Borodi, G., Culea, E., Tetean, R., Structural and magnetic properties of zinc ferrite incorporated in amorphous matrix, Ceramics International, 37, 33433349, 2011.

[59] Arora, S., Kundu, V., Goyal, D.R., Maan, A.S., Effect of stepwise replacement of LiF by $\mathrm{ZnO}$ on structural and optical properties of $\mathrm{LiF}$. $\mathrm{B}_{2} \mathrm{O}_{3}$ glasses, Turkish Journal of Physics, 37, 229-236, 2013.

[60] Agarwal, A., Sheoran, A., Sanghi, S., Bhatnagar, V., Gupta, S.K., Arora, M., Structural investigation and electron paramagnetic resonance of vanadyl doped alkali niobium borate glasses, Spectrochimica Acta A, 75, 964-969, 2010. 
[61] Jiao, Q., Yu, X., Xu, X., Zhou, D., Qiu, J., Relationship between Eu ${ }^{3+}$ reduction and glass polymeric structure in $\mathrm{Al}_{2} \mathrm{O}_{3}$-modified borate glasses under air atmosphere, Journal of Solid State Chemistry, 202, 65-69, 2013.

[62] Razali, W.A.W., Azman, K., Hashim, S., Alajerami, Y.S.M., Syamsyir, S.A., Mardhiah, A., Ridzwan, M.H.J., Physical, Structural, and Luminescence Studies of $\mathrm{Nd}^{3+}$ Doped $\mathrm{MgO}-\mathrm{ZnO}$ Borate Glass, Optics and Spectroscopy, 115, 701-707, 2013.

[63] Kilic, G., Issever, U.G., Ilik, E., Characterization of $\mathrm{Er}^{3+}$ doped ZnTeTa semiconducting oxide glass, Journal of Materials Science: Materials in Electronics, 30(9), 89208930, 2019.

[64] Issever, U.G., Kilic, G., Peker, M., Ünaldi, T., Aybek, A.S., Effect of low ratio $V^{5+}$ doping on structural and optical properties of borotellurite semiconducting oxide glasses, Journal of Materials Science: Materials in Electronics, 30 (16), 15156-15167, 2019. 